\title{
Influence of Austempering Temperatures on the Microstruc- ture and Mechanical Properties of Austempered Ductile Cast Iron
}

\author{
Regita Bendikiene ${ }^{1 *}$, Antanas Ciuplys ${ }^{1}$, Ramunas Cesnavicius ${ }^{2}$, Audrius Jutas ${ }^{2}$, Aliaksandr Bahdanovich ${ }^{3}$, \\ Dzianis Marmysh ${ }^{3}$, Aleh Nasan ${ }^{3}$, Liudmila Shemet ${ }^{3}$ and Sergei Sherbakov ${ }^{3}$
}
1 Department of Production Engineering, Faculty of Mechanical Engineering and Design, Kaunas University of Technology, Studentu str. 56, 51424 Kaunas, Lithuania; regita.bendikiene@ktu.lt (R.B.); antanas.ciuplys@ktu.lt (A.C.)
2 Department of Mechanical Engineering, Faculty of Mechanical Engineering and Design, Kaunas University of Technology, Studentu str. 56, 51424 Kaunas, Lithuania; ramunas.cesnavicius@ktu.lt (R.C.); audrius.jutas@ktu.lt (A.J.)
3 Department of Theoretical and Applied Mechanics, Faculty of Mechanics and Mathematics, Belarusian State University, Nezavisimosti ave 4, 220030 Minsk, Belarus; bogal@tut.by (A.B.); marmyshdenis@mail.ru (D.M.); oleg.nasan@gmail.com (A.N.); shemetla@yandex.ru (L.S.); sherbakovss@mail.ru (S.S.)
* Correspondence: regita.bendikiene@ktu.lt; Tel.: +370-698-01202

\begin{abstract}
The influence of the austempering temperatures on the microstructure and mechanical properties of austempered ductile cast iron (ADI) was investigated. ADI is nodular graphite cast iron, which owing to higher strength and elongation exceeds mechanical properties of conventional spheroidal graphite cast iron. Such a combination of properties is achieved by the heat treatment through austenitization, followed by austempering at different temperatures. The austenitization conditions were the same for all the samples: temperature $890^{\circ} \mathrm{C}$, duration $30 \mathrm{~min}$, and quenching in a salt bath. The main focus of this research was on the influence of the austempering temperatures $\left(270^{\circ} \mathrm{C}, 300^{\circ} \mathrm{C}\right.$, and $\left.330 \mathrm{C}\right)$ on the microstructure evolution, elongation, toughness and fatigue resistance of ADI modified by certain amount of $\mathrm{Ni}, \mathrm{Cu}$, and Mo. The Vickers and Rockwell hardness decreased from 535.7 to $405.3 \mathrm{HV} / 1$ ( 55.7 to $44.5 \mathrm{HRC}$ ) as the austempering temperature increased. Optical images showed the formation of graphite nodules and matrix composed of ausferrite; the presence of these phases was confirmed by an XRD diffraction pattern. A fracture surface analysis revealed several types of the mechanisms: cleavage ductile, transgranular and ductile dimple fracture. The stress-controlled mechanical fatigue experiments revealed that a $330^{\circ} \mathrm{C}$ austempering temperature ensures the highest fatigue life of ADI.
\end{abstract}

Keywords: austempering; fatigue; ausferrite; nodular graphite; austenitization; fracture

\section{Introduction}

Austempered ductile cast iron (ADI) is a heat-treatable engineering material due to a good compatibility of high strength, fluidity, toughness and ductility, as well as machinability, wear and fatigue resistance (the last three more suitable for steels), along with excellent design flexibility [1] and low cost that result in it appearing as a significant material in industry nowadays [2]. The outstanding properties of ADI are related with the formation of a unique combination of ausferrite and high carbon austenite, where transformation of the later is evoked by the austempering treatment [3]. The formed structure differs from that of austempered steel, where the microstructure is composed of ferrite and carbides. With such a structure, the cast iron is able to reach very high tensile strength (over $1600 \mathrm{MPa}$ ) and very good toughness (over $100 \mathrm{~J} / \mathrm{cm} 2$ ), combined with excellent fatigue resistance [4]. Products can be cast from ADI, which reduces the cost of the production and the product itself compared with the manufacturing cost of standard steel grades. From a machinability point of view, this material possesses a high work hardening 
coefficient alongside a low thermal conductivity [5]. These properties can be explained by higher number of sliding planes in the austenite, what assures better conditions for being deformed. As a result, a higher hardness and strength can be achieved during the deformation owing to the transformation of retained austenite into martensite. Moreover, high fluidity of ADI eliminates unnecessary hammering and assembling operations, thereby saving on the cost and weight of the final product.

From the abovementioned, it can be concluded that ADI can substitute for forged and cast steels in various application areas where self-lubrication characteristics and high mechanical properties are preferable. These areas cover the manufacturing of camshafts, crankshafts, piston rings and heavy engineering applications, as well as rails [6]. Other applications utilise the good tensile strength and toughness of ADI, alongside its high wear resistance to severe abrasion and erosion [4]. However, the wear resistance increases with a decrease of austempering temperatures, due to the formation of an oxide film and a high carbon martensitic structure [7]. For such applications, controlling the microstructure of ADI should also be considered, owing to the adaptability of its various wear systems to either abrasion, adhesion or to contact or tribo-fatigue.

To achieve all the unique properties of cast iron, a two-stage heat treatment is necessary: austenitization at $815-950{ }^{\circ} \mathrm{C}$; and austempering at $230-400{ }^{\circ} \mathrm{C}$ for various durations, with a subsequent air cooling to room temperature. The result of first stage - martensite - and carbide from the second stage two, has a negative effect on the ductility and toughness. Thus, the optimum combination of ductility and toughness is achieved during the period between the end of the first and the onset of the second stage. This period is referred as the "process window". A smaller window results in some martensite, while a larger window results in a bainitic iron with an already progressed embrittlement reaction $[8,9]$. If there is no process window, the iron will have less ductility. That is why for commercial ADI grades, a wider process window is preferable.

Conventional and two-step austempering processes have been compared with regard to the microstructure evolution and wear resistance [10]. A single-step process was utilised at four different temperatures $\left(270,300,330\right.$ and $\left.360^{\circ} \mathrm{C}\right)$ for $120 \mathrm{~min}$, with subsequent cooling to room temperature, while a two-step austempered batch was quenched at $260{ }^{\circ} \mathrm{C}$ in a salt bath for $5 \mathrm{~min}$ with a subsequent austempering at the four abovementioned temperatures. It was observed that the two-step process ensures the formation of a refined structure, even hardness, tensile properties and a slightly improved impact toughness, although no effect on the corrosion resistance was noted.

It has also been found that a higher volume fraction of high carbon stabilised austenite is formed at a lower austempering temperature $\left(250^{\circ} \mathrm{C}\right)$, which reduces the cutting forces required for the machining of ADI [3]. A research study [11] concentrated on the mechanical properties of low alloyed ADI that was austenized at $826^{\circ} \mathrm{C}$, and then austempered at $385,360,315$, and $287^{\circ} \mathrm{C}$. Due to an increase of the proeutectoid ferrite content, the yield and the ultimate tensile strength were gradually reduced while the fracture toughness decreased with the lower austempering temperature. Thus, it is obvious that the phases, their distribution and the volume fraction all play a significant role in the mechanical properties of ductile cast iron.

The results showed [12] that the fracture toughness of ADI alloyed with copper and copper nickel is lower than that of unalloyed ADI at the same hardness values. This indicates that the addition of alloying elements does not improve the fracture toughness in ADI. The fracture toughness of two alloyed ADIs at four different temperatures was also studied [13], where it was found that the fracture toughness was only a function of the volume fraction of ferrite and the retained austenite. The fracture toughness reached its maximum when the content of the retained austenite in the matrix was $30 \mathrm{vol} . \%$.

Although the material shows some wear resistance: the wear rate decreases when the matrix hardness increases [14]. Furthermore, the high load wear resistance of ADI is not yet sufficient and cannot be achieved using conventional ADI processing. To reach the necessary wear and corrosion resistance, a carbidic austempered ductile iron (CADI) was composed. Three different processes were proposed to reach the formation of carbides in 
CADI: adding $\mathrm{Nb}, \mathrm{Mo}, \mathrm{V}, \mathrm{Cr}$, etc. [15-17]; controlling the cooling rate [18]; and reducing the $\mathrm{Si}$ content. However, even achieving such a composition is not enough to gain a good impact toughness; therefore, an innovative heat treatment process involving close-tomelting temperature followed by an austempering treatment was analysed and reported [19]. Pre-treatment at $1100{ }^{\circ} \mathrm{C}$ for $10 \mathrm{~min}$ was followed by air cooling to the ambient temperature, then austempering at $880^{\circ} \mathrm{C}$ for $120 \mathrm{~min}$ with salt bath quenching, and finally austempering at $300{ }^{\circ} \mathrm{C}$ for $120 \mathrm{~min}$. The result was a $120 \%$ higher impact toughness than that of the traditional CADI treatment [19].

Rolling contact fatigue (RCF) damage is the most popular failure type in almost all mechanical systems where contacting components are subjected to a cyclic load [20]. The influence of the duration of the austempering on the RCF resistance was estimated using a twin-disk rolling configuration rig. It was found that the hardness of ADI decreased when the duration of process was increased (the amount of ausferrite increased, becoming more coarse), while at the same time a lower duration resulted in a higher hardness and longer fatigue life [21]. In addition, the influence of the surface finish - either manual or automatic - on the RCF resistance and surface properties was analysed. The main findings were reported as: polishing by grinding results in both a smoothened surface and an increased fatigue life [22]. Laser spot hardening was also considered as one method of surface treatments, as a measure to reduce the scuffing and rolling contact fatigue of $\mathrm{Cu}-\mathrm{Ni}$ ADI [23]. However, it was discovered that a higher volume of formed martensite (higher hardness) and residual compressive stresses were among the results of laser hardening.

As the mechanical properties of ADI depend on the peculiarities of the heat treatment [24]: the austenitization temperature, duration of quenching in the salt bath, and on the proper selection of austempering temperatures that do not eliminate the right alloying process, it was decided to analyse the effects of three sets of heat treatment processes on the mechanical properties of ADI alloyed with higher amount of $\mathrm{Cu}, \mathrm{Ni}$, and $\mathrm{Mo}$.

To determine the performance of any ductile iron, the quality index (QI) including the tensile strength and the elongation was introduced [25], but as ADI is used for railways and other moving components the QI was modified by a wear resistance unit [7]. The authors [7] proved that the QI changes with an increase of the austempering temperature: the higher the QI, the better the strength and wear properties of the ADI. Since this study showed that a lower austempering temperature was enough to reach required properties, this results in almost $8 \%$ of energy savings when compared with high an austempering temperature. This leads to less energy consumption, less gas emission and promotes the concept of green manufacturing.

The main aim of the present study was to analyse the influence of the austempering temperatures on the microstructure formation and mechanical properties of ADI.

\section{Materials and Methods}

The chemical composition of austempered ductile cast iron analysed in this work was modified by accurately chosen amounts (wt.\%) of Mo $0.4-0.6$, Ni $0.5-0.6$, and $\mathrm{Cu} 1.1-$ 1.3 according to the Material Standard MKC 77.080.10, 77.040. High Fatigue Resistance Ductile Cast Iron with Nodular Shaped Graphite (in Russian). The chemical composition is presented in Table 1.

Table 1. Chemical composition of ADI.

\begin{tabular}{cccccccccccc}
\hline Element & $\mathbf{C}$ & $\mathbf{S i}$ & $\mathbf{M n}$ & $\mathbf{C r}$ & $\mathbf{M o}$ & $\mathbf{N i}$ & $\mathbf{C u}$ & $\mathbf{M g}$ & $\mathbf{T i}$ & $\mathbf{F e}$ \\
\hline wt. $\%$ & $3.5-3.7$ & $2.5-2.8$ & $0.2-0.3$ & $0.02-0.06$ & $0.4-0.6$ & $0.5-0.6$ & $1.1-1.3$ & $0.03-0.07$ & $0.01-0.12$ & Bal. \\
\hline
\end{tabular}

These elements $(\mathrm{Mo}, \mathrm{Ni}, \mathrm{Cu})$ can enlarge the so-called "process window" $[8,11]$ - the time interval between the very end of the first stage of austenitization $\left(\gamma \rightarrow \alpha+\gamma_{\mathrm{HC}}, \mathrm{HC}-\right.$ high carbon austenite) and the beginning of second stage reaction ( $\gamma_{\mathrm{HC}} \rightarrow \alpha+$ carbide), which shows the allowable austempering duration for the processing of this ductile iron required to reach the optimum mechanical properties $[9,11]$. 
The metallographic samples were examined using optical microscope Olympus BX51TF equipped with an QImaging G0-21 camera, while the image analysis was performed with QCapture Pro software. The SEM analysis was conducted on the ZEISS EVO MA10 in the secondary electron mode at a $20 \mathrm{kV}$ accelerating voltage. An X-ray energy dispersive spectrometer (EDS) Bruker Quantax with Xflash 6/10 and Esprit software was used for the investigation of the element distribution.

In order to evaluate the influence of the austempering temperature on the mechanical properties of ADI, three sets of samples were prepared according to the following schedule: 1) austenitization at $890^{\circ} \mathrm{C}$ for $30 \mathrm{~min} ; 2$ ) quenching in a salt bath (potassium nitrate, sodium nitrate, sodium nitrite) for $5 \mathrm{~s} ; 3$ ) austempering at the three different temperatures $270{ }^{\circ} \mathrm{C}, 300{ }^{\circ} \mathrm{C}$ and $330^{\circ} \mathrm{C}$ for a constant duration of $40 \mathrm{~min}$; and 4) air quenching. During this stage of the treatment, a salt bath was used to minimise the surface oxidation and decarburization effect [26].

The Vickers hardness of the longitudinal sections was measured by using a Mitutoyo Hardness Testing Machine HM-200 (Mitutoyo Corporation, Japan) under the load of $9.807 \mathrm{~N}$.

Rockwell hardness tests were done with the Universal hardness tester Verzus 750CCD.

Hardness and fatigue tests were accomplished at room temperature for each of the austempering conditions. Five samples were tested from each set, and just the average values were reported.

The nodularity was assessed visually via a Nicon Measuring Microscope using the data processing software E-MAX Version 7.01.

The X-ray diffraction was performed with a conventional DRON diffractometer in a Bragg-Brentano configuration. A CuK $\alpha$ wavelength radiation (tube voltage of $30 \mathrm{kV}$ and a current of $20 \mathrm{~mA}$ ) filtered with a secondary beam flat pyrolytic graphite crystal monochromator was used. Data was collected over the angular range $2 \theta=20-90^{\circ}$ with a step of $0.02^{\circ}$ and a counting time of $2 \mathrm{~s} / \mathrm{step}$. The equipment was calibrated by the corundum $\alpha-\mathrm{Al}_{2} \mathrm{O}_{3}(99.9 \%)$ standard. The XRD data of samples was analysed with the TOPAS 4.1 software program, using the Rietveld crystal structure refinement method.

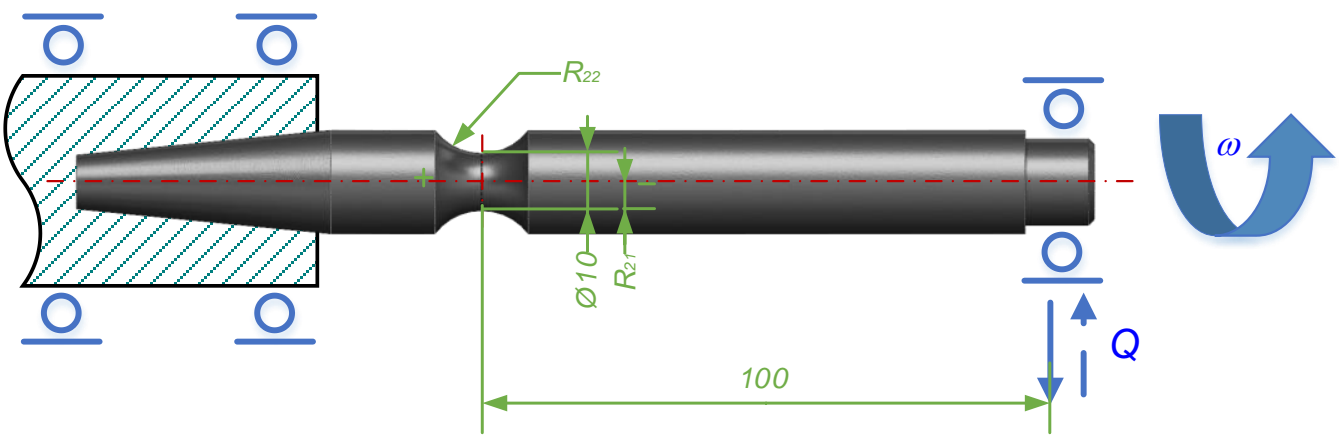

Figure 1. Fatigue test sample.

Test machine SI-O3 M and fatigue test samples as provided in Figure 1 were used to give a comparative analysis on the rotating fatigue of the samples [27]. In order to find out lifetime of the samples, rotational bending conditions were created and set according to the following series of stress amplitude, $\sigma_{a}$ (in MPa): 800, 700. 600, 500, 400, 300 and 243. This revealed (Figure 2) what kinds of stresses and signs may act at the extreme crosssectional points of a rotating sample until it breaks. According to the experimental setup, the theoretical changes in the normal $\sigma_{11}$ and shear $\sigma_{12}$ stresses acting at the critical points A, B, C, D depend upon an angle of revolutions $\varphi=\varphi t$. If the experimental stress amplitude is $\sigma_{a}=$ const, then the distribution of the stresses $\sigma_{11}$ and $\sigma_{12}$ is a function of the angle $\omega t$ that may by generally written in the form: $\sigma=\sigma(\omega, t)=\sigma_{11}$ and $\tau=\tau(\omega, t)=\sigma_{12}$. The change in the theoretical stresses $\sigma_{11}$ and $\sigma_{12}$ are shown in Figure 2. 


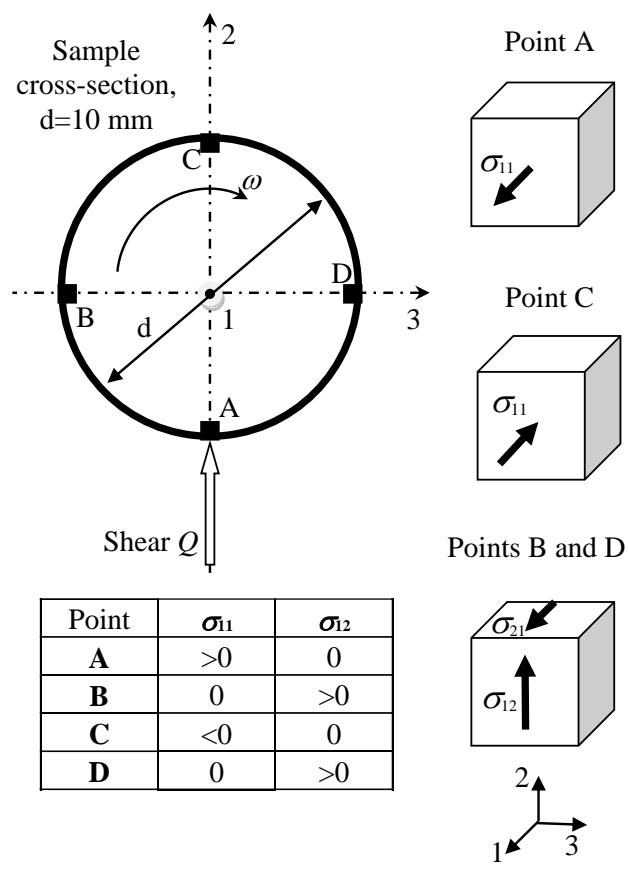

(a)

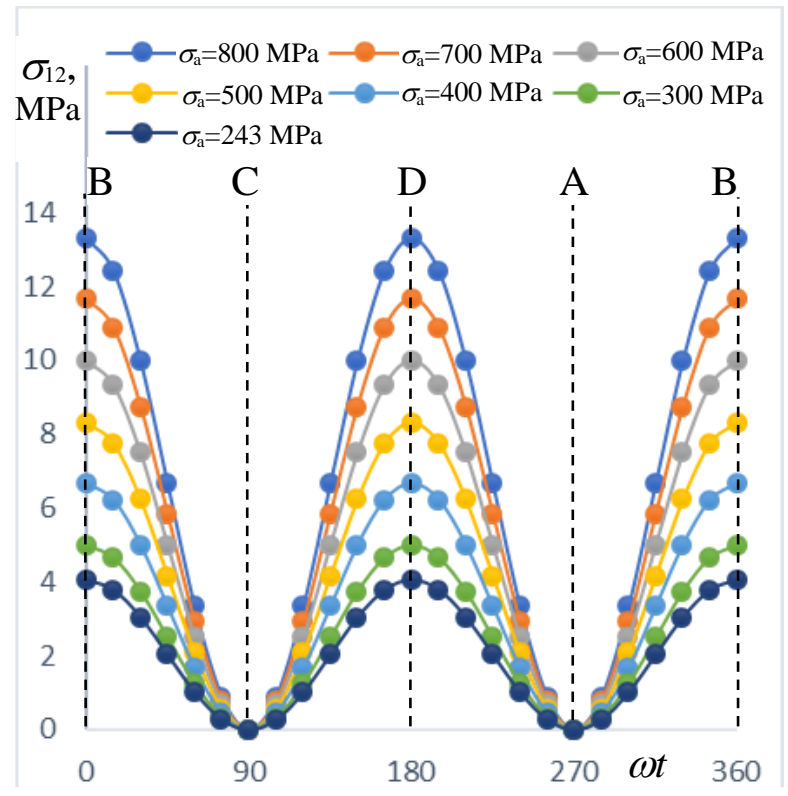

(c)

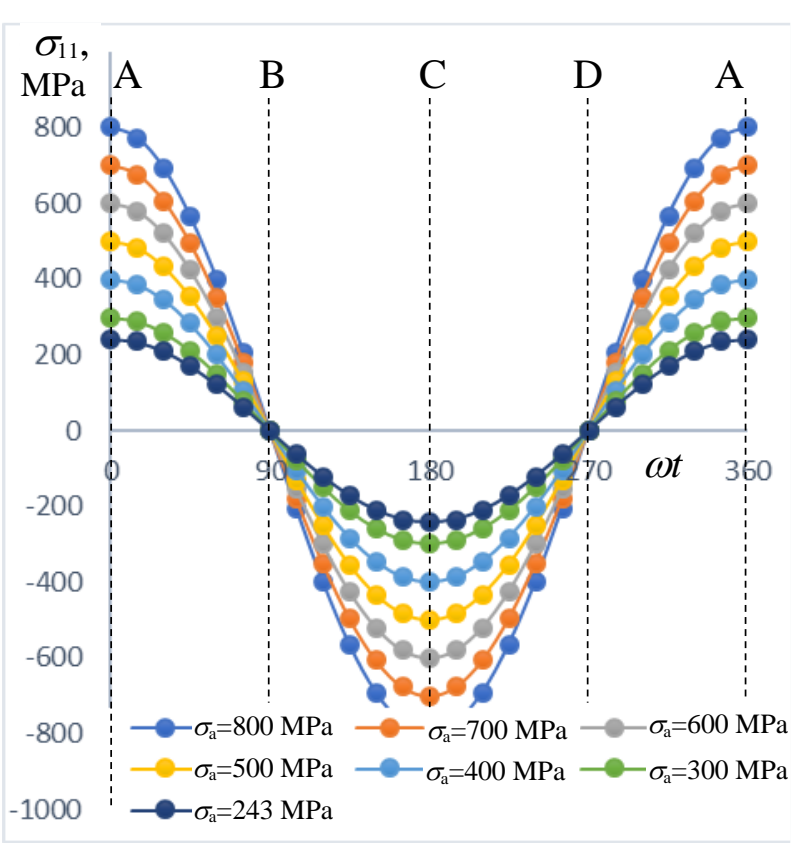

(b)

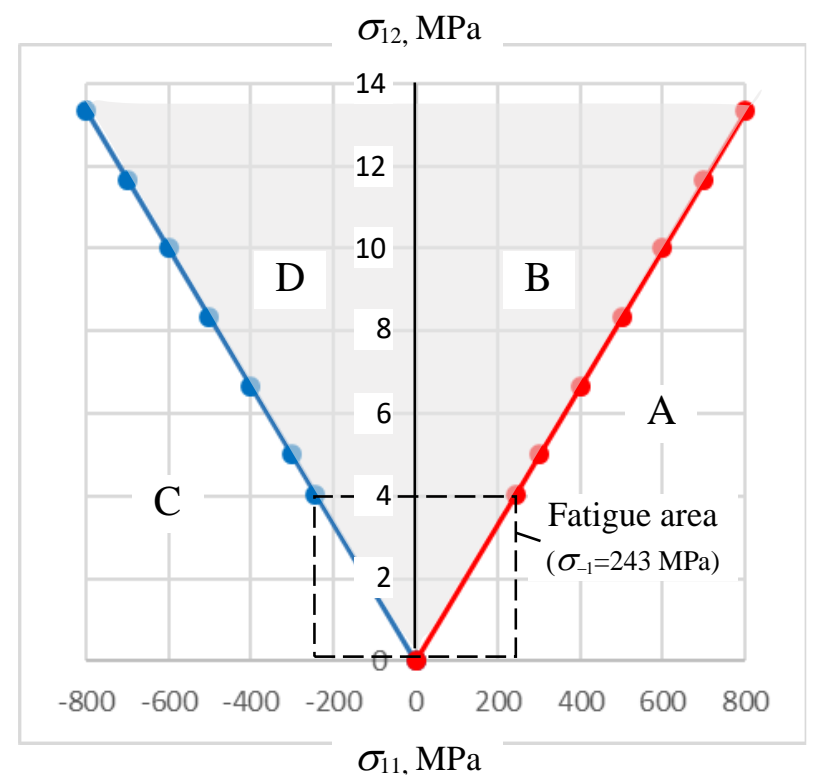

(d)

Figure 2. Theoretical representation of angle of revolutions $\omega t$ versus normal $\sigma_{11}$ and shear $\sigma_{12}$ stresses acting at critical points A, B, C, D in the sample according to the experimental setup

The set-up of the test points A, B, C, D (Figure 2a) was performed according to the critical change in the stress value and its sign (Table 2). The points were located inside the material close to the cylindrical surface to guarantee the stress extremes; while in the volumetric representative elements (RVE), it is shown what kind of stress they were subjected to: $\sigma_{11}$ and $\sigma_{22}$. In Figure $2 \mathrm{~b}$ and c, the normal stress $\sigma_{11}$ and shear stress $\sigma_{2}$, respectively, are shown varying in the range of $0-180$ degrees based on the product of the angular velocity $\omega$ and the time $t$, in accordance with the cyclic stress amplitude $\sigma_{a}$ indicating the seven test series. Figure $2 \mathrm{~d}$ represents a quantitative comparison when the normal stress $\sigma_{11}$ matches the shear stress $\sigma_{12}$; the points $\mathrm{A}, \mathrm{B}, \mathrm{C}$ and $\mathrm{D}$ are located in various areas of the graph because of the stress sign differences: point $\mathrm{A}$ if $\sigma_{11}>0$, point $\mathrm{C}$ if $\sigma_{11}<0$, and 
points $\mathrm{B}$ and $\mathrm{D}$ if $\sigma_{12}>0$ (grey area), while the dashed frame shows the area of the fatigue limit $\sigma_{-1}=243 \mathrm{MPa}$.

Table 2. Extreme values of normal $\sigma_{11}$ and shear $\sigma_{12}$ stresses at the Points A, B, C, D caused by cyclic stress amplitude $\sigma_{a}$, MPa.

\begin{tabular}{ccccccccc}
\hline \multicolumn{2}{c}{$\sigma_{a}$} & 800 & 700 & 600 & 500 & 400 & 300 & 243 \\
\hline \multirow{2}{*}{$\sigma_{11}$} & $\mathrm{~A}, \mathrm{C}$ & \pm 800 & \pm 700 & \pm 600 & \pm 500 & \pm 400 & \pm 300 & \pm 243 \\
\cline { 2 - 9 } & $\mathrm{B}, \mathrm{D}$ & 0 & 0 & 0 & 0 & 0 & 0 & 0 \\
\hline \multirow{2}{*}{$\sigma_{12}$} & $\mathrm{~A}, \mathrm{C}$ & 0 & 0 & 0 & 0 & 0 & 0 & 0 \\
\cline { 2 - 9 } & $\mathrm{B}, \mathrm{D}$ & 13.333 & 11.667 & 10.0 & 8.333 & 6.667 & 5.0 & 4.05 \\
\hline
\end{tabular}

At points A, B, C and D, the normal $\sigma_{11}$ and shear $\sigma_{12}$ stresses reached their extreme values as presented in the Table 2 .

\section{Results and discussion}

The test sequence was accomplished according to the experimental setup presented in Figure 3. An EDS analysis followed by a heat treatment process prepared the samples for the further micro examination that included: hardness tests, microstructure analyses, nodularity and XRD analyses. The chosen fatigue analysis input data was a rotation speed of $3000 \mathrm{rpm}$ and a bending loading $Q$. These values are determined to obtain a constant stress amplitude during every cycle. After the fatigue tests, the fracture surfaces were analysed.

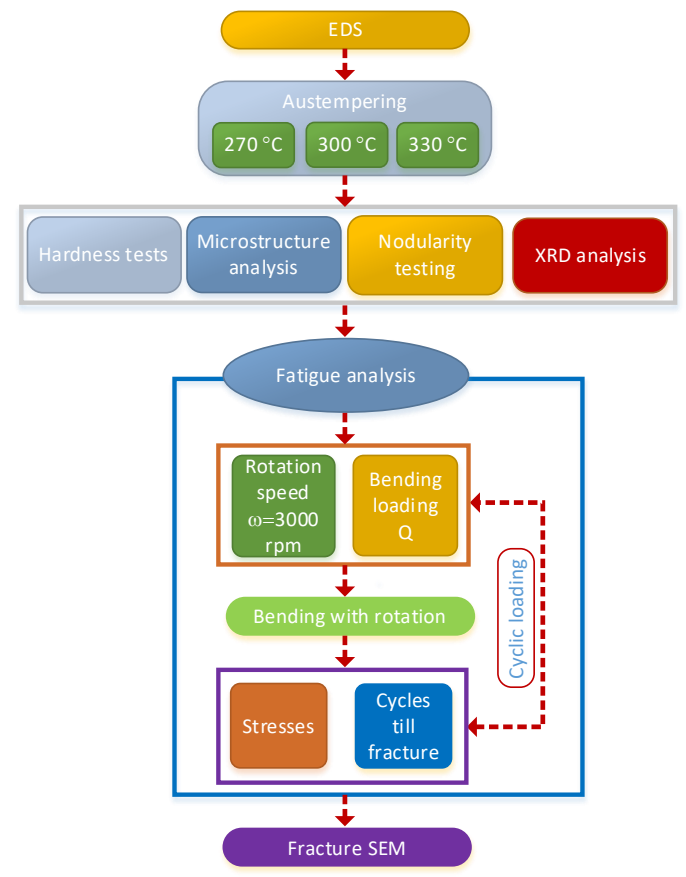

Figure 3. Experimental setup of research.

The three alloying elements $\mathrm{Mo}, \mathrm{Ni}, \mathrm{Cu}$ were chosen in order to avoid an austeniteto-pearlite transformation upon cooling to the austempering treatment temperature, and to alter the kinetics of the austenite decomposition during the austempering to obtain ausferrite [9,28]. Firstly, these elements affect the nodularity, the nodule count of graphite and the solidification behaviour, and later influences the abovementioned solid to solid phase transformation. The first alloying element, Mo, stabilizes ferrite and directly increases the hardenability due to having a strong affinity to carbon, while the austenite stabilizing elements $\mathrm{Ni}$ and $\mathrm{Cu}$ have a low affinity towards carbon. Such a combination of 
alloying elements and their specific ratio $[29,30]$ was expected to achieve the expected mechanical properties after austempering.

EDS analysis performed on the ductile cast iron modified with $\mathrm{Ni}, \mathrm{Cu}$, and $\mathrm{Mo}$ revealed a considerable amount of those elements (Figure 4).

The Vickers hardness values HV/1 were registered on the longitudinal sections of the samples. The values of hardness are indicated in Table 3 . The austempering temperature affected the material hardness: the maximum values were achieved when the lowest austempering temperature of $270{ }^{\circ} \mathrm{C}$ was utilized. This could be explained by optimum content of ausferrite. As the austempering temperatures increased, the content of the retained austenite increases, but the amount of acicular ferrite gradually decreased. Both the retained austenite and the ferrite coarsening resulted in a decrease of the hardness [10,31], while the volume fraction of high-carbon austenite increased gradually as did the carbon content [32] because a part of the carbides dissolve into the matrix.

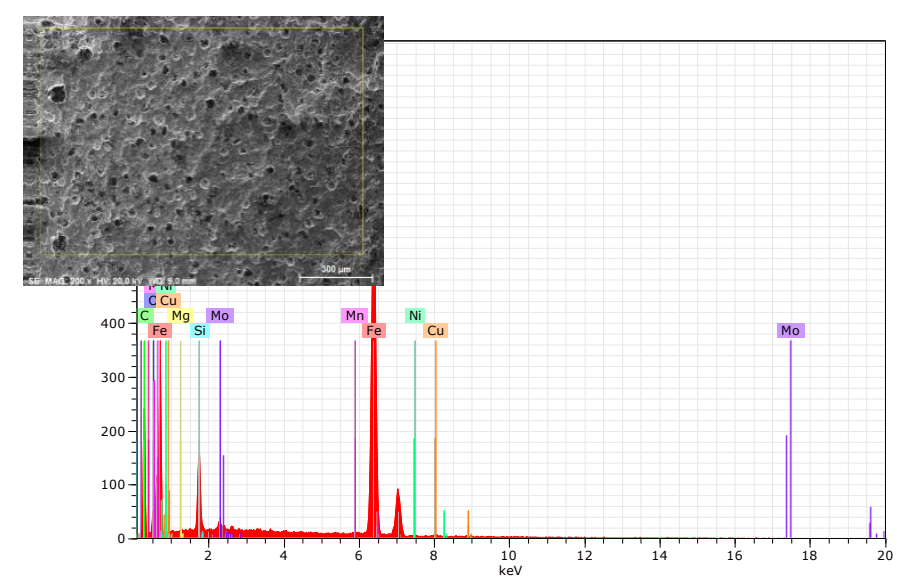

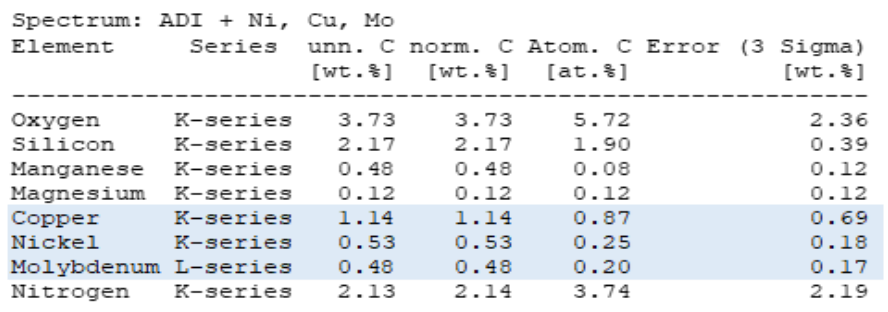

Figure 4. Elemental analysis of modified ductile cast iron.

Table 3. Extreme values of normal $\sigma_{11}$ and shear $\sigma_{12}$ stresses at the Points A, B, C, D caused by cyclic stress amplitude $\sigma_{a}, \mathrm{MPa}$.

\begin{tabular}{llllllllll}
\hline Austempering & \multicolumn{3}{c}{$\mathbf{2 7 0} \mathbf{C}$} & \multicolumn{3}{c}{$\mathbf{3 0 0}{ }^{\circ} \mathbf{C}$} & \multicolumn{3}{c}{$30^{\circ} \mathbf{C}$} \\
\hline Hardness & Ave. & Min & Max & Ave. & Min & Max & Ave. & Min & Max \\
\hline HV/1 & 644.1 & 535.7 & 783.8 & 616.3 & 485.3 & 574.6 & 441.5 & 405.3 & 498.5 \\
\hline HRC & 55.7 & & & 50.7 & & & 44.5 & & \\
\hline
\end{tabular}

Cast ductile iron (Figure 5a) has a typical bull's eye structure which is formed largely of pearlitic matrix and a higher or lower density of graphite nodules (nodule count), as well as ferrite surrounding the graphite $[11,28]$. Such a distribution of structural phases causes work hardening and affects the machinability, while at the same time the absence of pro-eutectoid ferrite causes a low ductility. The presence of higher amount of the ferrite stabilizing element Mo $(0.4-0.6 \mathrm{wt} . \%)$ causes lower graphite nodule count, which adversely influences the segregation and size of the carbides [28]. The nodularity of the graphite inclusions calculated using the image analyzer software was $85 \%$ [7]; moreover, it was noted that the nodularity was almost constant at all austempering temperatures. 
During the austempering process of the cast samples, in the region where the two phases ferrite and austenite coexist, the pearlitic matrix transforms to austenite and a certain amount of ferrite, which is still influenced by the austenitizing temperature. The austenite, gathered at the grain boundaries of the ferrite, starts to grow through the ferrite grains. The result of such growth is the formation of a ferritic matrix layered with carbonenriched austenite. Further nucleation of the austenite at the grain boundaries of the primary ferrite leads to the enrichment and saturation of the austenite with carbon, while the later diffusion of carbon becomes complicated due to the end of the ferrite grain growth.

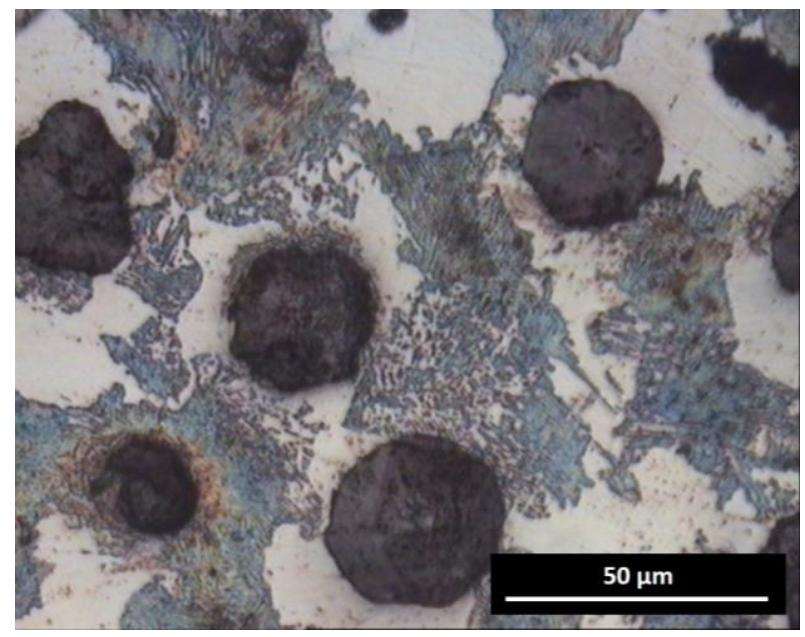

(a)

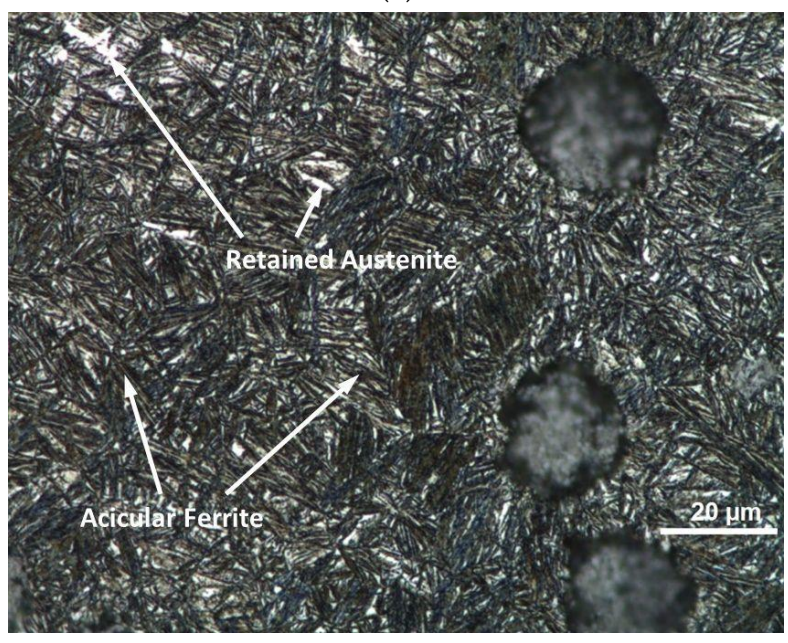

(c)

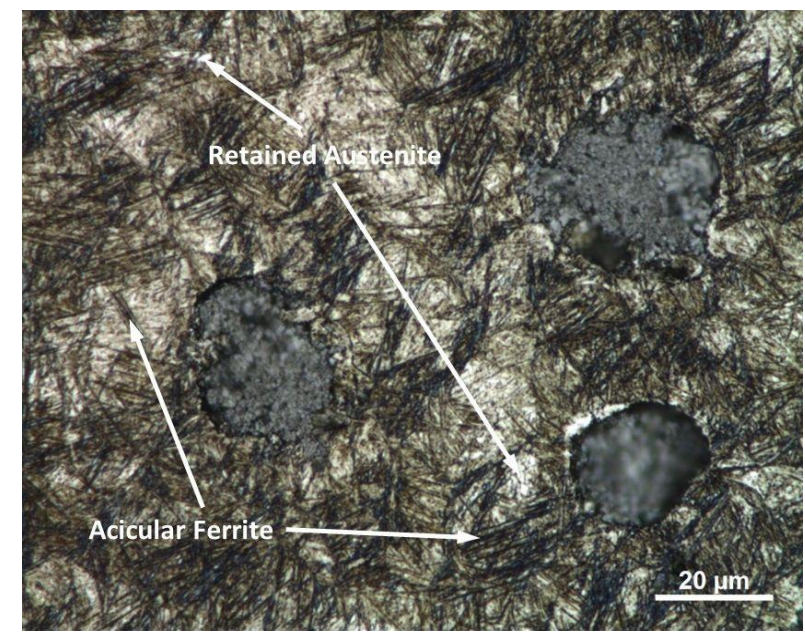

(b)

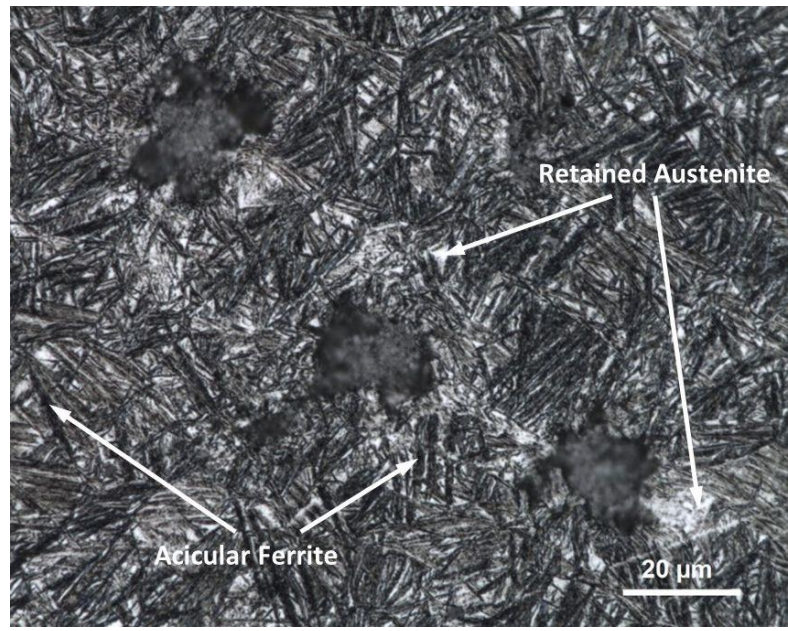

(d)

Figure 5. The optical micrographs of ADI: (a) as cast structure, austempered at (b) $270{ }^{\circ} \mathrm{C},(\mathbf{c}) 300{ }^{\circ} \mathrm{C},(\mathbf{d}) 330{ }^{\circ} \mathrm{C}$.

At the lower temperature $\left(270{ }^{\circ} \mathrm{C}\right)$, the microstructure of the samples (Figure $\left.5 \mathrm{~b}\right)$ consisted mainly of a matrix of ausferrite, which is acicular ferrite and carbon enriched austenite, retained austenite and graphite nodules. During the isothermal heat treatment process, tiny acicular ferrite nucleates formed around the nodules under the effect of high potential energy [26], with the further growth of the ferrite platelets leading to the formation the carbon enriched austenite.

The ferritic-pearlitic matrix (Figure 5a) under the effect of austempering, was altered to a mixture of acicular ferrite and retained austenite. Appreciable amounts of Ni, Mo, and $\mathrm{Cu}$ presented in the ADI, segregated around the graphite nodules, therefore, some ferrite could be observed in the surrounding areas of the graphite nodules [11]. This was an effect of the austempering process.

On increasing the austempering temperature to $300^{\circ} \mathrm{C}$ or to $330{ }^{\circ} \mathrm{C}$ (Figure $5 \mathrm{c}$ and $\mathrm{d}$, respectively) more ausferrite was formed, and its feathery needles became coarser [2]. This was detected even in the two-step austempering process [10]. Since the austempering 
temperatures were low, the austempering process will have a greater degree of supercooling, resulting in a larger nucleation driving force of the ferrite. A higher temperature of austempering results in a higher quantity of coarse ausferrite, while at the same time the Lever rule dictates that the volume of ausferrite decreases with an increased process temperature.

During the austempering treatment, bainitic ferrite replaces austenite, which is indistinguishable from the ferrite. This happens because there is an excess carbon distribution in the retained austenite, which stabilises without any risk of transforming into martensite while cooling to the room temperature. No martensite was observed in the microstructures, indicating a proper selection of the austempering schedule. It was also expected to have a finer structure with the lower austempering temperature [29].

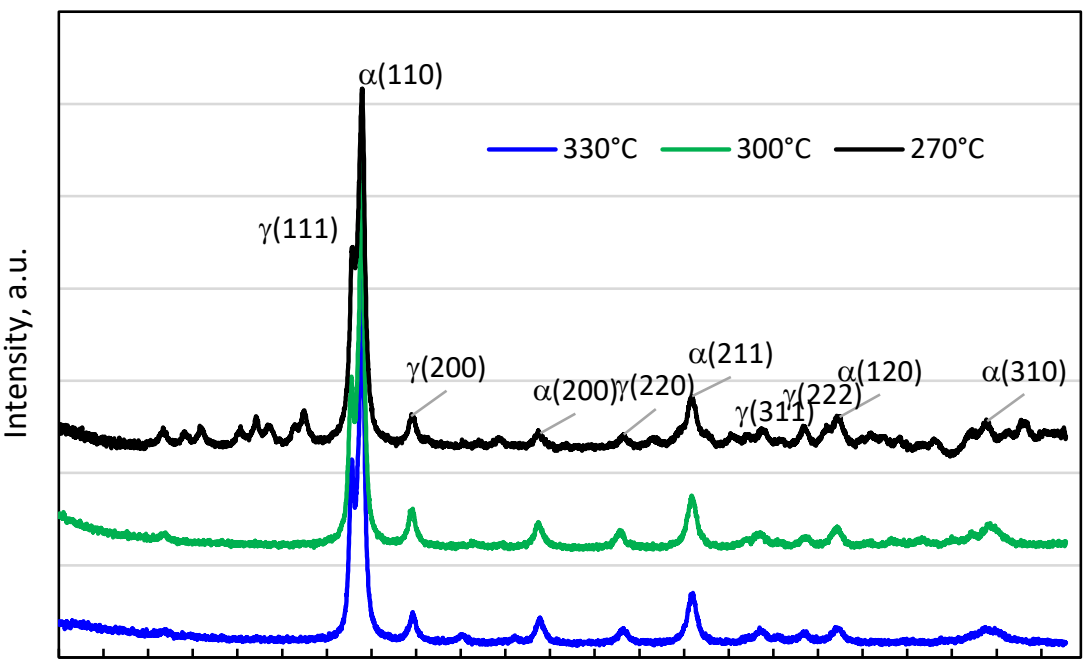

$\begin{array}{lllllllllllllllllll}10 & 15 & 20 & 25 & 30 & 36 & 41 & 46 & 51 & 56 & 61 & 66 & 71 & 76 & 81 & 87 & 92 & 97 & 102107112117122\end{array}$

Diffraction angle $2 \theta$, deg

Figure 6. XRD patterns of austempered samples.

The composed phases in the samples were quantified by XRD diffraction pattern (Figure 6). The X-ray reflected microscopic analysis showing the formation of a predominantly ausferrite structure. The planes of a face centered cubic lattice (fcc) $\gamma(111), \gamma(200)$, $\gamma(220), \gamma(311)$, and $\gamma(222)$ were identified in all samples with slightly different intensities. The formation of a body centered phase (bcc) was presented by the existence of $\alpha(110)$, $\alpha(200), \alpha(211)$ and $\alpha(120)$ planes [4,14]. The peaks of fcc and bcc were located close to each other, which indicates the formation of acicular ferrite in carbon-enriched austenite (ausferrite). The lower austempering temperature of $270{ }^{\circ} \mathrm{C}$ showed a higher intensity of the (111) plane, basically owing to the formation of high carbon retained austenite. This can be attributed to the decrease in the nucleation potential of ferrite lamellar, due to the decrease in the cooling rate during quenching [31].

Experiments of cantilever-type rotating bending (Figure 1) were performed on the samples treated at different austempering temperatures, to find out the fatigue life of ADI.

It can be seen in Figure 7 that the endurance limit is the same (243 MPa) for all the specimens treated at different austempering temperatures. At the loading levels below the defined endurance limit (horizontal red dashed line), the samples of austempered cast iron withstood more than $10^{8}$ cycles. The purple arrows indicate that, after the loading cycles of $10^{8}$ the austempered cast iron samples did not have fractures. 


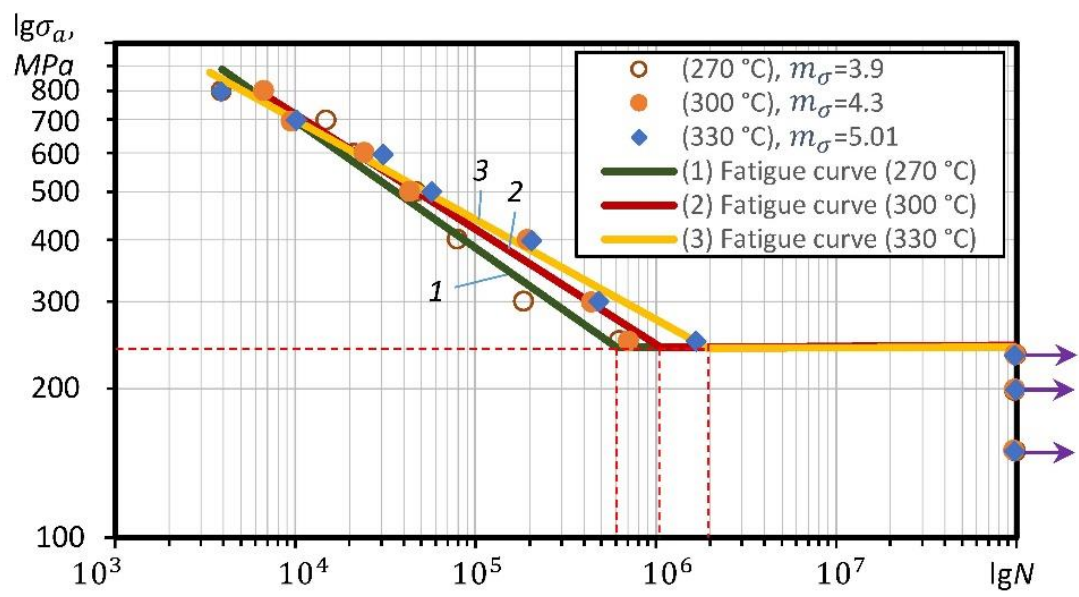

Figure 7. Mechanical fatigue of ADI treated at different austempering temperature.

At higher loading levels (above the horizontal red dashed line) all the samples of cast iron had very similar fatigue life tendencies. At lower loading levels, the samples (Figure 7, Curve 3) of cast iron tempered at $330^{\circ} \mathrm{C}$ had a better fatigue life compared to the samples treated at $270{ }^{\circ} \mathrm{C}$ and $300{ }^{\circ} \mathrm{C}$ (Figure 7, Curve 1 and Curve 2, respectively). The stresscontrolled fatigue experiments enable us to conclude that the specimens of cast iron austempered at $330{ }^{\circ} \mathrm{C}$ had the highest fatigue life. The abscissa of the inflection point of the fatigue curve $N_{G \alpha}$ for the cast iron had $N_{G \alpha}=6.4 \cdot 10^{5}$ cycles at the austempering temperature of $270{ }^{\circ} \mathrm{C}$ (Curve 1), $N_{G \alpha}=1.1 \cdot 106$ at $300{ }^{\circ} \mathrm{C}$ (Curve 2) and $N_{G \alpha}=2.0 \cdot 10^{6}$ at $330{ }^{\circ} \mathrm{C}$ (Curve 3). Also, the fatigue curve slope parameter $m_{\alpha}$ was defined $m_{\alpha}=3.9$ for $270{ }^{\circ} \mathrm{C}$ (Curve 1), $m_{\alpha}=4.3$ for $300{ }^{\circ} \mathrm{C}$ (Curve 2) and $m_{\alpha}=5.01$ for $330{ }^{\circ} \mathrm{C}$ (Curve 3).

The fatigue curve slope parameter $m_{\alpha}$ can be expressed as:

$$
m_{\alpha}=\cot \alpha,
$$

where $\alpha$ is the inclination angle. The slope parameter of the fatigue curve describes the rate of the fatigue resistance change on the number of cycles until the instant limiting state is reached.

The fatigue fracture surfaces (Figure 8) revealed the graphite nodules distribution (Figure 9), the size of the nodules, and the graphite density (nodule count) characteristic for each austempering temperature.

The fracture surfaces of the samples were analysed in order to determine the fracture mechanism at different austempering temperatures. The graphite nodules act as discontinuities in the structure. When the load is applied, the area surrounding the graphite undergoes a plastic deformation, causing a decohesion at the nodule/surrounding interface. That is why at first, micro-cracks form in this interface (Figure 8). These micro-cracks act as concentrators of stresses, leading to the growth and propagation of cracks in the surrounding areas adjacent to the nodules.

The austempered samples mainly consisted of ausferrite and retained austenite, while the presented carbide particles acted as a barrier to the slipping, causing stress concentrations during loading. This facilitated the propagation of cracks [33]. The samples showed cleavage ductile fractures throughout the surfaces (Figure 8a-c), which indicates the brittle nature of the fracture [34]. This can be characterized by the formation of relatively large cavity size comparing with the nodule sizes. It appears that the stress-induced martensitic transformation assisted in the growth of brittle cracks and subsequently lowered the fracture toughness. The samples from all austempering temperatures revealed both transgranular and ductile dimple fracture. But it was observed that, due to the plastic deformation, the clearance between the nodules and cavities was larger when austempering temperature was $300^{\circ} \mathrm{C}$ and $330^{\circ} \mathrm{C}$. A distinct feature observed in the fracture surface was a quasi-cleavage fracture with some fine dimple areas. The fracture surfaces of the ADI were compared with those of conventional ductile iron and [35], as a result, tighter clearances between the nodules and cavities were revealed. It was reported that a large 
amount of high carbon austenite is not preferable, to reach necessary mechanical properties and fracture toughness [34]. Instead, in order to have higher mechanical properties and fracture toughness, the austenite should be in a specific arrangement: in between the needles of bainite and ferrite.

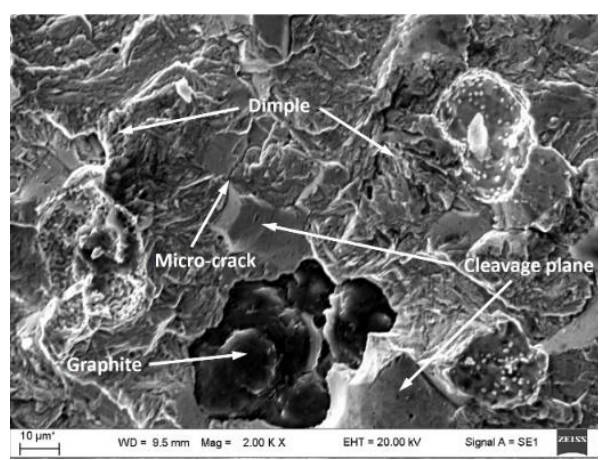

(a)

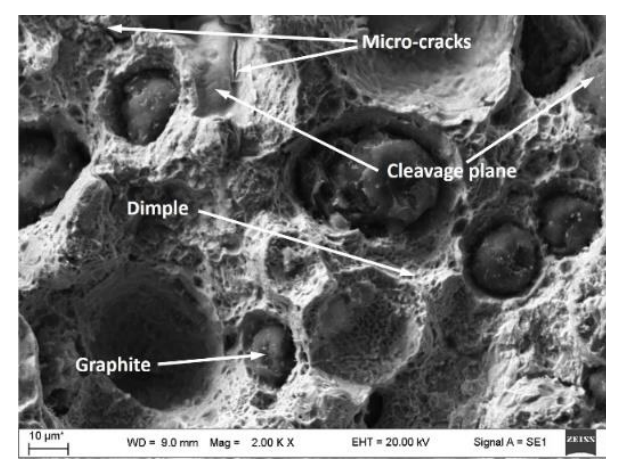

(b)

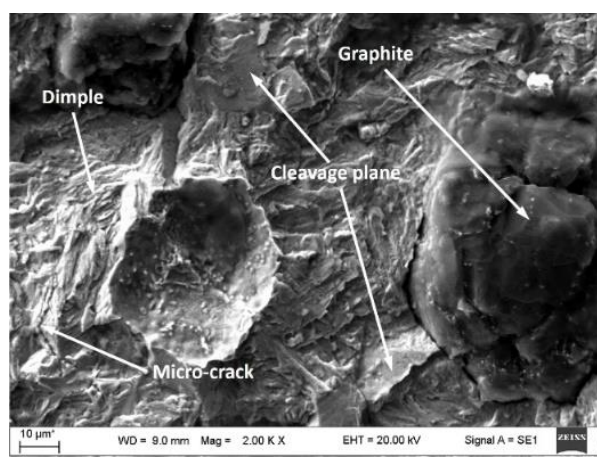

(c)

Figure 8. The fatique fracture surfaces of ADI austempered at: (a) $270{ }^{\circ} \mathrm{C}$, (b) $300^{\circ} \mathrm{C},(\mathbf{c}) 330^{\circ} \mathrm{C}$.

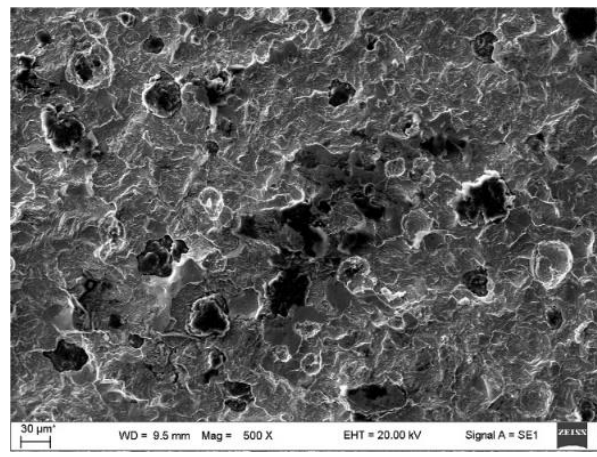

(a)

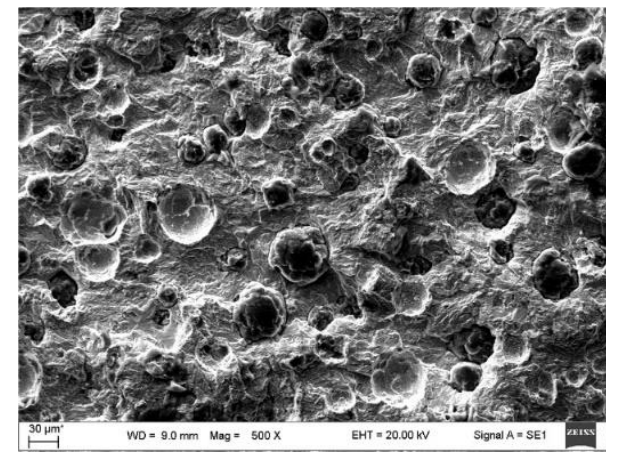

(b)

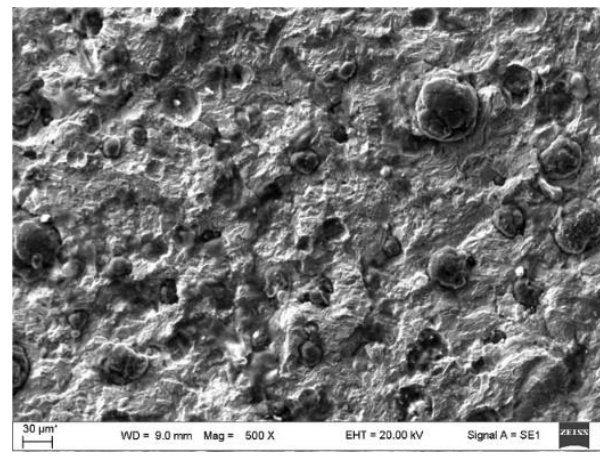

(c)

Figure 9. The distribution of graphite nodules: (a) $270{ }^{\circ} \mathrm{C},(\mathbf{b}) 300{ }^{\circ} \mathrm{C},(\mathbf{c}) 330^{\circ} \mathrm{C}$.

\section{Conclusions}

Austempered ductile cast iron, modified with wt.\% Mo $0.4-0.6, \mathrm{Ni} 0.5-0.6$, and $\mathrm{Cu}$ $1.1-1.3$ and austempered at the different temperatures $270{ }^{\circ} \mathrm{C}, 300^{\circ} \mathrm{C}$, and $330^{\circ} \mathrm{C}$ showed satisfactory mechanical properties. This was owing to the accurately chosen amount of the alloying elements and a composed microstructure which mainly consisted of acicular ferrite and austenite. The Vickers (HV/1) and Rockwell (HRC) hardness values gradually reduced with an increase of the austempering temperature from 644.1 to $441.5 \mathrm{HV} / 1$ and from 55.7 to $44.5 \mathrm{HRC}$. This was caused by the increase of the ausferrite concentration. Therefore, it has been confirmed that the morphology of acicular ferrite, the carbon content in austenite, as well as the volume fraction of stable austenite strongly depends on two parameters in the austempering process: temperature and time. As a result, the final mechanical properties of ADI can be effectively controlled by these parameters. Fine ausferrite is formed by using a $270{ }^{\circ} \mathrm{C}$ austempering temperature, while the structure tends to coarsen when $300{ }^{\circ} \mathrm{C}$ and $330{ }^{\circ} \mathrm{C}$ temperatures are used with a same duration of the process.

Several types of damage mechanisms were observed after evaluating surface fractures: cleavage ductile, transgranular and ductile dimple fractures. The stress-controlled mechanical fatigue experiments revealed that a $330^{\circ} \mathrm{C}$ austempering temperature ensures the highest fatigue life of austempered ductile cast iron.

Author Contributions: Conceptualization, A.B.; methodology, A.B.; validation, R.C. and A.J.; formal analysis, D.M., A.N. and L.S.; investigation, D.M., A.N. and L.S.; resources, S.S.; data curation, A.C.; writing-original draft preparation, R.B.; writing-review and editing, A.C.; visualization, 
A.C., R.C. and A.J.; supervision, R.B and S.S.; project administration, R.B.; funding acquisition, S.S. All authors have read and agreed to the published version of the manuscript.

Acknowledgments: This work was supported by the Research Council of Lithuania [Grant No. SLB-19-6]; and performed in cooperation with the Belarusian State University.

Conflicts of Interest: The authors declare no conflict of interest in this work.

\section{References}

1. Echeverría, M.D.; Moncada, O.J.; Sikora, J.A. Influence of the dimensional change, and its dispersion, on the fabrication size tolerances of austempered ductile iron (ADI) parts: comparison with SAE 4140 steel. ISIJ Int. 2001, 41, 25-30, doi:10.2355/isijinternational.41.25.

2. Han, J.M.; Zou, Q.; Barber, G.C.; Nasir, T.; Northwood, D.O.; Sun, X.C.; Seaton, P. Study of the effects of austempering temperature and time on scuffing behavior of austempered Ni-Mo-Cu ductile iron. Wear 2012, 290-291, 99-105, doi:10.1016/J.WEAR.2012.05.003.

3. Parhad, P.; Dakre, V.; Likhite, A.; Bhatt, J. The impact of cutting speed and depth of cut on cutting force during turning of austempered ductile iron. Materials Today: Proceedings 2019, 19, 663-669.

4. Pedro, D.I.; Dommarco, R.C. Rolling contact fatigue resistance of Carbidic Austempered Ductile Iron (CADI). Wear 2019, 418-419, 94-101, doi:10.1016/j.wear.2018.11.005.

5. Putatunda, S.K.; Kesani, S.; Tackett, R.; Lawes, G. Development of austenite free ADI (austempered ductile cast iron). Mater. Sci. Eng. A 2006, 435-436, 112-122, doi:10.1016/j.msea.2006.07.051.

6. Radulovic, B.; Bosnjak, B.; Harding, R.; Pop-Tonev, K.; Asanovic, V. The influence of austenitising temperature on the microstructure and mechanical properties of low-alloyed Ni-Mo-Cu austempered ductile iron. Mater. Technol. 2000, 34, 207-212.

7. Sellamuthu, P.; Samuel, D.G.H.; Dinakaran, D.; Premkumar, V.P.; Li, Z.; Seetharaman, S. Austempered ductile iron (ADI): Influence of austempering temperature on microstructure, mechanical andwear properties and energy consumption. Metals (Basel). 2018, 8, doi:10.3390/met8010053.

8. Guerra L, F. V.; Bedolla-Jacuinde, A.; Mejía, I.; Zuno, J.; Maldonado, C. Effects of boron addition and austempering time on microstructure, hardness and tensile properties of ductile irons. Mater. Sci. Eng. A 2015, 648, 193-201, doi:10.1016/j.msea.2015.09.066.

9. Tanaka, Y.; Kage, H. Development and application of austempered spheroidal graphite cast iron. Mater. Trans. JIM 1992, 33, 543-557, doi:10.2320/matertrans1989.33.543.

10. Nan, R.; Fu, H.; Yang, P.; Lin, J.; Guo, X. Microstructure Evolution and Wear Resistance of Cu-Bearing Carbidic Austempered Ductile Iron after Austempering. J. Mater. Eng. Perform. 2020, 29, 2440-2459, doi:10.1007/s11665-020-04788-9.

11. Panneerselvam, S.; Putatunda, S.K.; Gundlach, R.; Boileau, J. Influence of intercritical austempering on the microstructure and mechanical properties of austempered ductile cast iron (ADI). Mater. Sci. Eng. A 2017, 694, 72-80, doi:10.1016/j.msea.2017.03.096.

12. Eric, O.; Sidjanin, L.; Miskovic, Z.; Zec, S.; Jovanovic, M.T. Microstructure and toughness of CuNiMo austempered ductile iron. Mater. Lett. 2004, 58, 2707-2711, doi:10.1016/j.matlet.2004.02.041.

13. Putatunda, S.K. Influence of austempering temperature on fracture toughness of a low manganese austempered ductile iron (ADI). Mater. Manuf. Process. 2001, 16, 245-263, doi:10.1081/AMP-100104304.

14. Zhang, H.; Wu, Y.; Li, Q.; Hong, X. Mechanical properties and rolling-sliding wear performance of dual phase austempered ductile iron as potential metro wheel material. Wear 2018, 406-407, 156-165, doi:10.1016/j.wear.2018.04.005.

15. Han, C.F.; Sun, Y.F.; Wu, Y.; Ma, Y.H. Effects of Vanadium and Austempering Temperature on Microstructure and Properties of CADI. Metallogr. Microstruct. Anal. 2015, 4, 135-145, doi:10.1007/s13632-015-0197-1.

16. Han, C.F.; Wang, Q.Q.; Sun, Y.F.; Li, J. Effects of Molybdenum on the Wear Resistance and Corrosion Resistance of Carbidic Austempered Ductile Iron. Metallogr. Microstruct. Anal. 2015, 4, 298-304, doi:10.1007/s13632-015-0215-3.

17. Yang, P.; Fu, H.; Lin, J.; Cheng, H.; Lei, Y. Experimental and ab initio study of the influence of a compound modifier on carbidic ductile iron. Metall. Res. Technol. 2019, 116, 306-316, doi:https://doi.org/10.1051/metal/2018124.

18. Peng, Y.C.; Jin, H.J.; Liu, J.H.; Li, G.L. Influence of cooling rate on the microstructure and properties of a new wear resistant carbidic austempered ductile iron (CADI). Mater. Charact. 2012, 72, 53-58, doi:10.1016/j.matchar.2012.07.006.

19. Penghui, Y.; Hanguang, F.; Guolu, L.; Jinhai, L.; Xuebo, Z. Microstructures and properties of carbidic austempered ductile Iron containing Fe3C particles and superfine ausferrite. Mater. Des. 2020, 186, 108363, doi:10.1016/j.matdes.2019.108363.

20. Sadeghi, F.; Jalalahmadi, B.; Slack, T.S.; Raje, N.; Arakere, N.K. A Review of Rolling Contact Fatigue. J. Tribol. 2009, 131, doi:https://doi.org/10.1115/1.3209132.

21. Wang, B.; He, M.; Barber, G.C.; Schall, J.D.; Tao, C.; Sun, X. Rolling contact fatigue resistance of austempered ductile iron processed at various austempering holding times. Wear 2018, 398-399, 41-46, doi:10.1016/j.wear.2017.11.022.

22. Colombo, D.A.; Dommarco, R.C.; Basso, A.D. Rolling contact fatigue behavior of dual-phase austempered ductile iron. Wear 2019, 418-419, 208-214, doi:10.1016/j.wear.2018.11.009.

23. Zammit, A.; Abela, S.; Betts, J.C.; Michalczewski, R.; Kalbarczyk, M.; Grech, M. Scuffing and rolling contact fatigue resistance of discrete laser spot hardened austempered ductile iron. Wear 2019, 422-423, 100-107, doi:10.1016/j.wear.2019.01.061. 
24. Samaddar, S.; Das, T.; Chowdhury, A.K.; Singh, M. Manufacturing of Engineering components with Austempered Ductile Iron - A Review. Materials Today: Proceedings 2018, 5, 25615-25624.

25. Fatahalla, N.; Hussein, O. Microstructure, Mechanical Properties, Toughness, Wear Characteristics and Fracture Phenomena of Austenitised and Austempered Low-Alloyed Ductile Iron. Open Access Libr. J. 2015, 2, 1-16, doi:http://dx.doi.org/10.4236/oalib.1101012.

26. Wang, B.; Barber, G.C.; Qiu, F.; Zou, Q.; Yang, H. A review: Phase transformation and wear mechanisms of single-step and dual-step austempered ductile irons. J. Mater. Res. Technol. 2020, 9, 1054-1069, doi:10.1016/j.jmrt.2019.10.074.

27. Sosnovskiy, L.A.; Bogdanovich, A. V.; Yelovoy, O.M.; Tyurin, S.A.; Komissarov, V. V.; Sherbakov, S.S. Methods and main results of Tribo-Fatigue tests. Int. J. Fatigue 2014, 66, 207-219, doi:10.1016/j.ijfatigue.2014.04.006.

28. Saal, P.; Meier, L.; Li, X.; Hofmann, M.; Hoelzel, M.; Wagner, J.N.; Volk, W. In Situ Study of the Influence of Nickel on the Phase Transformation Kinetics in Austempered Ductile Iron. Metall. Mater. Trans. A Phys. Metall. Mater. Sci. 2016, 47, 661671, doi:10.1007/s11661-015-3261-1.

29. Konca, E.; Tur, K.; Koç, E. Effects of alloying elements (Mo, Ni, and Cu) on the austemperability of GGG-60 ductile cast Iron. Metals (Basel). 2017, 7, doi:10.3390/met7080320.

30. Bahdanovich, A.; Bendikiene, R.; Cesnavicius, R.; Ciuplys, A.; Grigas, V.; Jutas, A.; Marmysh, D.; Mazaleuski, A.; Nasan, A.; Shemet, L.; et al. Research on tensile behaviour of new structural material MoNiCa. Medziagotyra 2019, 25, 292-296, doi:10.5755/j01.ms.25.3.23079.

31. Elmasry, N.; Mahdy, A.; Kandil, A. Influence of austempering temperature on microstructure and properties of ductile irons. J. Al Azhar Univ. Eng. Sect. 2013, 8, 122-128.

32. Nan, R.; Fu, H.; Yang, P.; Lin, J.; Lei, Y. Effect of austenitizing temperature on the microstructure evolution and properties of Cu-bearing CADI. Mater. Test. 2019, 61, 865-874, doi:10.3139/120.111394.

33. Batra, U. Fracture behavior and mechanism in austempered ductile iron. J. Fail. Anal. Prev. 2005, 5, 75-81, doi:10.1361/154770205X65936.

34. Putatunda, S.K. Influence of austempering temperature on microstructure and fracture toughness of a high-carbon, highsilicon and high-manganese cast steel. Mater. Des. 2003, 24, 435-443, doi:10.1016/S0261-3069(03)00090-6.

35. Refaey, A.; Fatahalla, N. Effect of microstructure on properties of ADI and low alloyed ductile iron. J. Mater. Sci. 2003, 38, 351-362, doi:10.1023/A:1021177902596. 